Sebastian Kubas

Uniwersytet Śląski

\title{
Partycypacja katowickiej wspólnoty lokalnej w wyborach do organów władzy samorządu miejskiego i rad jednostek pomocniczych. Analiza zjawiska na podstawie wybranych zmiennych
}

DOI: $10.19195 / 1643-0328.20 .12$

Słowa kluczowe: wybory samorządowe w Katowicach, frekwencja, głosy nieważne

\section{Wprowadzenie}

Fenomen wyborów samorządowych wydaje się ciekawym zjawiskiem pod kątem badań, których wyniki pozwalają na przedstawienie różnych aspektów towarzyszących poszczególnym elekcjom. Można analizować zachowania i preferencje wyborcze, system wyborczy i jego ewolucję, wpływ wyborów na lokalne sceny polityczne, tworzenie się i funkcjonowanie elit władzy. Wszystkie te kwestie, a także wiele niewymienionych, pomagają określić zakres i poziom znaczenia wyborów samorządowych dla kształtowania się i istnienia społeczeństwa obywatelskiego, a także zdecentralizowanego państwa demokratycznego. Poparcie dla demokracji, jako reżimu politycznego, wyraża się w możliwości udziału obywateli w sprawowaniu władzy. Tę możliwość ogranicza stosunkowo duży rozmiar terytorialny współczesnego państwa, wielomilionowy skład ludności, a także wielość i skomplikowany charakter spraw będących przedmiotem procesów decyzyjnych. Podstawowym elementem legitymizacji demokratycznego sprawowania władzy są wybory. Zakres i poziom uczestnictwa w nich wyraża poparcie i zainteresowanie obywateli wpływem na władzę. Partycypacja obywateli w wyborach jest czynnikiem, który zostanie poddany analizie w niniejszym artykule.

Wybory samorządowe mają pewne specyficzne cechy. Struktura i mechanizmy poszczególnych wyborów samorządowych w Polsce zmieniały się w trakcie ostatniego ćwierćwiecza. Pierwsze wybory samorządowe z 27 maja 1990 roku były częścią rozpoczynającej się wówczas reformy samorządowej. Jak zauważa Andrzej K. Piasecki, stała się ona najlepiej ocenianym fragmentem transformacji ustrojowej państwa, a wybory do rad były najbardziej masową procedurą bezpośredniego uczestnictwa w rywalizacji po- 
litycznej i sprawowaniu władzy ${ }^{1}$. Pierwsze dwie elekcje samorządowe (lata 1990 i 1994) obejmowały wyłącznie rady gmin, trzecia (1998 rok) została poszerzona o wybór radnych powiatu (miasta na prawach powiatu), a także sejmików województw, od czwartej (2002 rok) można wybierać wójtów, burmistrzów i prezydentów.

Celem artykułu jest ukazanie specyfiki zakresu partycypacji wyborczej mieszkańców Katowic w wyborach do organów władzy lokalnej, przede wszystkim na poziomie jednostek pomocniczych. Nie są one jednak jedynym przedmiotem analizy, gdyż w ogólnym zakresie zostaną osadzone w kontekście ogólnopolskich trendów związanych z wyborami samorządowymi, a także wyborami do rady miasta Katowice. Analiza zjawiska partycypacji wyborczej na poziomie wyborów do rad jednostek pomocniczych zostanie dokonana na podstawie dwóch podstawowych kryteriów: frekwencji oraz głosów nieważnych. Te dwie zmienne pozwalają ukazać poziom istotności elekcji danego typu dla elektoratu. Zarówno poprzez partycypację w procesie wyłaniania lokalnych włodarzy, jak i oddanie głosu nieważnego możliwe staje się udzielenie odpowiedzi na pytanie o zakres angażowania się obywateli w życie publiczne jednostki, która stanowi ich najbliższe otocznie. Analiza zjawiska prezentowanego w artykule w ujęciu temporalnym obejmuje wszystkie cykle wyborcze od 1990 do 2014 roku.

Przystępując do procesu badawczego, należy zadać pytanie na temat oceny wyborów do rad jednostek pomocniczych, a także wyborów do rady miasta i na urząd prezydenta w Katowicach, którą formułują mieszkańcy stolicy województwa śląskiego. Ocena ta jest każdorazowo wydawana w momencie głosowania wyłaniającego reprezentantów władzy lokalnej i wyraża się nie tylko w akcie poparcia lub alternacji władzy, ale w samej chęci uczestnictwa w procedurze wyboru.

\section{Podejście teoretyczne do wyborów samorządowych}

Jak wspomniano we wprowadzeniu, wybory samorządowe charakteryzują pewne specyficzne cechy, które powodują, że ten typ elekcji jest odmienny od pozostałych. Można tu wskazać na większą depolityzację sceny podmiotów ubiegających się o wybór, co z kolei wpływa na niższą rangę głosowania strategicznego, charakterystyczne znaczenie systemu wyborczego, a także mniejszą istotność przypisywaną tego typu wyborom przez elektorat.

W przypadku wyborów samorządowych poziom depolityzacji jest większy niż w wyborach parlamentarnych, prezydenckich i do Parlamentu Europejskiego. Szczególnie $\mathrm{w}$ wyborach do gminnych organów uchwałodawczych i wykonawczych można zauważyć, że udział kandydatów pochodzących z ugrupowań niebędących terenowymi oddziałami ogólnopolskich partii politycznych jest wysoki. Depolityzacja jest zauważalna także na poziomie wyborów do rad powiatów. Najmniejszą wartość ta zmienna przyjmuje w wyborach do sejmików województw. W tabeli 1 przedstawiono przykładowy rozkład mandatów dla partii politycznych i komitetów lokalnych na poziomie gmin, powiatów i województw, który wykształcił się po wyborach samorządowych w 2006 roku. Ciekawe może się okazać porównanie tego zjawiska z sytuacją, która wystąpiła w wybo-

1 A.K. Piasecki, Wybory w Polsce, Kraków 2012, s. 32. 
rach w 1990 roku. Wówczas w radach gmin partie polityczne zdobyły łącznie 11\% mandatów. Pozostałe miejsca przypadły ruchowi obywatelsko-solidarnościowemu².

Tabela 1. Procentowy rozkład mandatów zdobytych przez podmioty uczestniczące w wyborach samorządowych w 2006 roku

\begin{tabular}{c|c|c|c}
\hline & Rady gmin & Rady powiatów & Sejmiki województw \\
\hline Lokalne komitety & 71,92 & 42,12 & 1,43 \\
\hline Partie polityczne & 28,08 & 57,88 & 98,57 \\
\hline
\end{tabular}

Źródło: http://wiadomosci.gazeta.pl/Wiadmosci/1,802629,3738595.html (dostęp: 29.06.2010).

Mimo że udział partii politycznych w składach rad gmin wzrósł o kilkanaście procent w okresie 1990-2006, nadal jest on stosunkowo niski. Zdecydowaną przewagę na tym poziomie samorządowym mają lokalne komitety.

Poczucie, że kandydaci uczestniczący w wyborach samorządowych są bliżej wybierających, wpływa na fakt pojmowania aktu wyborczego w bardziej spersonalizowany sposób niż w innego typu wyborach, poza prezydenckimi. Na poziomie gmin najbardziej uwidacznia się to, że partyjne członkostwo kandydatów odgrywa mniejszą rolę niż ocena sylwetki samego kandydata. Rezultatem takiego podejścia jest większa swoboda w ocenie i wyborze kandydatów, gdyż elektorat może pominąć przynależność ideologiczną i partyjną kandydata ${ }^{3}$.

W przypadku systemu wyborczego zastosowanie w wyborach samorządowych różnych rozwiązań systemowych na kilku poziomach elekcji wymaga od elektoratu większej kompetencji i znajomości reguł wpływających na wybór przedstawicieli. Wynika to z odmienności sposobów przeliczania głosów na mandaty występujących w gminach, powiatach oraz województwach. Odmienny jest także mechanizm wyłaniający organy wykonawcze w gminach i miastach na prawach powiatu. Jednomandatowe okręgi wyborcze i formuła większości względnej wzmacniają dwupartyjność, natomiast wielomandatowe okręgi oraz formuła proporcjonalna są korzystniejsze dla istnienia i rozwoju wielu mniejszych partii. Obecne prawo samorządowe przyjęło rozwiązanie większościowe za wiążące przy wyłanianiu organów władzy uchwałodawczej w gminie oraz wykonawczej w gminie i mieście na prawach powiatu, natomiast proporcjonalne w przypadku organów uchwałodawczych w mieście na prawach powiatu, powiecie ziemskim i województwie ${ }^{4}$. Znajomość reguł wyborów jest ważna nie tylko $\mathrm{z}$ merytorycznego punktu widzenia, gdy dokonuje się wyboru kandydata odpowiadającego preferencjom wyborczym, ale także z technicznego punktu widzenia. Ten aspekt okazał się niezwykle istotny podczas wyborów samorządowych w 2014 roku, kiedy w wyborach na poziomie gmin zastosowano książeczki z listami podmiotów, zamiast pojedynczych dużych kart,

2 A. Bukowski, Komitety Obywatelskie - Ruch epoki przemian, „Studia Polityczne” 1994, nr 1-4, s. 70-71.

3 W. Wojtasik, Funkcje wyborów w III Rzeczypospolitej. Teoria i praktyka, Katowice 2012, s. 254-255.

4 W. Sokół, Ewolucja systemu wyborczego do samorządu terytorialnego (1990-1997) - zasady i konsekwencje, [w:] Samorząd terytorialny III Rzeczypospolitej. Dziesięć lat doświadczeń, red. S. Michałowski, Lublin 2002, s. 92-93. 
jak to było do tej pory. Przypuszcza się że, to ujęcie wpłynęło na większą, niż do tej pory, liczbę głosów nieważnych.

Charakterystyczną cechą wyborów samorządowych jest również przypisywana im swoista peryferyczność. Elekcje samorządowe są postrzegane przez elektorat za mniej ważne niż elekcje parlamentarne i prezydenckie. Podobnie, jak wybory do Parlamentu Europejskiego, wybory samorządowe mogą być traktowane jako elekcje drugiego porządku. Karlheinz Reif i Hermann Schmitt wysunęli koncepcję wyborów do Parlamentu Europejskiego jako drugorzędnych. Robert Wiszniowski, opierając się na wnioskach Schmitta, opisał właściwości takich wyborów, do których zaliczył: niższy poziom uczestnictwa politycznego wynikający z mniejszej polityzacji, postrzeganie wyborów przez elektorat, jako sposobu wyrażenia niezadowolenia z rządzących, mniejszy stopień głosowania strategicznego przy jednoczesnym zwiększeniu poziomu głosowania zgodnego $\mathrm{z}$ naturalnymi preferencjami ${ }^{5}$.

Waldemar Wojtasik uważa, że znaczenie drugorzędności odnosi się też do wyborów samorządowych. Owa drugorzędność może zostać poddana weryfikacji poprzez uwzględnienie oceny pięciu płaszczyzn: partycypacji wyborczej, preferencji do głosowania na partie małe, strategii partii politycznych, strategii budowania list wyborczych i konkretyzacji programów partii politycznych. W przypadku partycypacji wyborczej widoczne jest mniejsze zainteresowanie wyborami samorządowymi $\mathrm{w}$ porównaniu z parlamentarnymi i prezydenckimi. Czynnikiem, który wpływa na niższą frekwencję, może być stosunkowo nieostra rywalizacyjność, szczególnie w odniesieniu do komitetów lokalnych. Innym, równie istotnym czynnikiem jest większa pewność ostatecznego rozwiązania i zadowolenie z rządzących i kierunków realizowanej polityki. Jeżeli chodzi o poparcie dla małych partii, to rośnie ono na poziomie gmin i powiatów, gdzie większe szanse powodzenia mają lokalne komitety. Strategie pozycjonowania partii politycznych w trakcie wyborów samorządowych muszą się opierać na kilku mechanizmach. Po pierwsze, partie rywalizują z lokalnymi komitetami. Po drugie, partie ogólnokrajowe przenoszą rywalizację z poziomu parlamentarnego na samorządowy. Po trzecie, partie muszą uwzględnić wybory na urzędy wójtów, burmistrzów i prezydentów w całej strategii, co zmienia logikę rywalizacji. W odniesieniu do sposobu tworzenia list wyborczych, w przypadku wyborów samorządowych, partie polityczne i komitety lokalne przyjmują dwie odmienne metody. Podczas gdy partie konstruują listy przy uwzględnieniu na nich większej liczby liderów lokalnych, w komitetach przeważa metoda budowania listy wokół kandydata na wójta, burmistrza, prezydenta. Proces tworzenia programów politycznych i wyborczych partii należy uznać za trudny do jednoznacznego określenia, a w przypadku wyborów samorządowych specyfikę tego problemu komplikuje istnienie lokalnych i regionalnych poziomów życia publicznego ${ }^{6}$.

Wyniki badań empirycznych przeprowadzonych w 2009 roku potwierdzają drugorzędny charakter wyborów samorządowych, sytuując je za prezydenckimi i parlamen-

${ }^{5}$ R. Wiszniowski, Europejska przestrzeń polityczna. Zachowania elektoratu w wyborach do Parlamentu Europejskiego, Wrocław 2008, s. 208-209.

${ }^{6}$ W. Wojtasik, Drugorzędność wyborów samorządowych w teorii i badaniach empirycznych, [w:] Rola samorzadu terytorialnego $w$ modernizacji Polski, red. M. Barański, A. Czyż, S. Kubas, Katowice 2010, s. 255-260. 
tarnymi, a przed wyborami do Parlamentu Europejskiego. Innymi zmiennymi charakteryzującymi wybory samorządowe są między innymi bardziej prawicowe postawy respondentów, którzy przypisują większą istotność wyborom samorządowym. Wśród kategorii wiekowych, wybory samorządowe mają najwięcej zwolenników w grupie między 45. a 54. rokiem życia. Nieco więcej kobiet uznaje elekcje samorządowe za istotne, niż ma to miejsce w przypadku mężczyzn. Najliczniejszą grupę zwolenników mają wybory samorządowe wśród mieszkańców wsi, a najmniejszą w miastach do 20 tys. mieszkańców. Zauważa się, że wraz ze wzrostem poziomu wykształcenia rośnie również preferencja dla istotności wyborów samorządowych. W grupie osób, która uznała wybory samorządowe za najistotniejsze, przeważają ankietowani uznający swoją sytuację materialną za przeciętną?

Ze względu na swoją specyfikę wybory samorządowe spełniają nieco odmienne funkcje niż wybory innego typu. Marcin Bąkiewicz uważa, że takimi funkcjami są: odzwierciedlanie preferencji wyborczych elektoratu na podstawie programów wyborczych oraz popularności poszczególnych kandydatów w środowiskach lokalnych, kreowanie składu osobowego poszczególnych organów samorządowych w ramach selekcji dokonywanej podczas procesu wyborczego, legitymizowanie radnych poprzez nadanie im prawnego i politycznego tytułu do sprawowania mandatu, kształtowanie stabilnej większości rządzącej ${ }^{8}$. Natomiast Waldemar Wojtasik wylicza następujące funkcje wyborów samorządowych: przeniesienie na przedstawicieli prawa decydowania $\mathrm{w}$ imieniu obywateli, selekcja elit politycznych, funkcja legitymizująca, czyli nadanie prawomocności kandydatom, zapewnienie kontroli rządzących i egzekwowanie politycznej odpowiedzialności, funkcja programowa, wyrażanie woli wyborców co do kierunków dystrybucji władzy, wyłanianie stabilnej większości zdolnej do rządzenia ${ }^{9}$.

Uwzględniając powyższe założenia teoretyczne, autor spróbuje określić poziom istotności wyborów samorządowych na przykładzie Katowic, uwzględniając jedną z pięciu płaszczyzn wymienionych przez Waldemara Wojtasika. Chodzi o partycypację wyborczą, która charakteryzuje wybory samorządowe jako drugorzędowe. Podczas analizy procesu partycypacji uwaga będzie skupiona na dwóch zmiennych: frekwencji i głosach nieważnych.

\section{Frekwencja jako zmienna partycypacji obywatelskiej}

Podstawową zmienną charakteryzującą partycypację wyborczą jest frekwencja. Prezentuje ona poziom zainteresowania społeczeństwa udziałem $\mathrm{w}$ podejmowaniu publicznie istotnych decyzji. Partycypacja w wyborach jest powszechnie uznawana za pozytywne

7 Projekt „Preferencje polityczne 2009. Postawy - identyfikacje - zachowania” został opracowany przez Agnieszkę Turską-Kawę oraz Waldemara Wojtasika. Badania empiryczne przeprowadzono w okresie od listopada do grudnia 2009 roku wśród ogólnopolskiej, reprezentatywnej próby dorosłych Polaków, dobranej w sposób kwotowo-warstwowy $(\mathrm{n}=1086)$. Zob. Ibidem, s. 260-267.

8 M. Bąkiewicz, Finansowe aspekty wyborów samorządowych, [w:] Samorząd terytorialny. Studium politologiczne, red. J. Marszałek-Kawa, Toruń 2007, s. 11.

9 W. Wojtasik, Funkcje wyborów..., s. 255-276. 
zachowanie, co ukazują wyniki badań, w których obywatele deklarują gotowość uczestnictwa $\mathrm{w}$ wyborach na wyższym poziomie niż ma to miejsce $\mathrm{w}$ trakcie samych elekcji. W badaniach z 2010 roku respondenci zadeklarowali udział $\mathrm{w}$ wyborach samorządowych na wyższym poziomie niż pokazały wyniki samych wyborów ${ }^{10}$.

Wskazany przez Roberta Wiszniowskiego niższy poziom partycypacji obserwowany w wyborach drugiego rzędu, a potwierdzony przez Waldemara Wojtasika w odniesieniu do wyborów samorządowych, powinno się poddać weryfikacji dotyczącej wyborów samorządowych w intersującym tu katowickim obszarze badań. Warto zacząć analizę od ukazania poziomu partycypacji obywateli w wyborach do rady miasta Katowic, w województwie śląskim, Polsce i gminach (miastach na prawach powiatów).

Tabela 2. Frekwencja w wyborach samorządowych w wybranych obszarach

\begin{tabular}{c|c|c|c|c}
\hline Wybory & Katowice (\%) & $\begin{array}{c}\text { woj. śląskie } \\
\text { (do 1998 roku } \\
\text { woj. katowickie) (\%) }\end{array}$ & Polska (\%) & $\begin{array}{c}\text { Gmina w Polsce } \\
\text { (od 1998 roku miasta } \\
\text { na prawach powiatu) (\%) }\end{array}$ \\
\hline 1990 & 40,6 & 39,6 & 42,27 & $40,28^{*}$ \\
\hline 1994 & 25 & 28,6 & 33,78 & $28,05^{*}$ \\
\hline 1998 & 33,95 & 34 & 45,45 & 39,84 \\
\hline 2002 & 32,91 & 37,98 & 44,24 & 44,12 \\
\hline 2006 & 37,99 & 39,98 & 45,99 & 47,46 \\
\hline 2010 & 39,43 & 42,94 & 47,32 & 49,57 \\
\hline 2014 & 30,62 & 35,29 & 46,64 & 48,13 \\
\hline
\end{tabular}

Uwaga: frekwencja podawana jest w odniesieniu do I tury wyborów

*gmina miejska licząca powyżej 40 tys. mieszkańców.

Źródło: Obwieszczenie Generalnego Komisarza Wyborczego PKW z dnia 31 maja 1990 roku o zbiorczych wynikach wyborów do rad gmin oraz na obszarze kraju, przeprowadzanych w dniu 27 maja 1990 roku. M.P. 1990 Nr 21, poz. 170; Obwieszczenie PKW z dnia 23 czerwca 1994 roku o zbiorczych wynikach wyborów do rad gmin oraz do Rady m. st. Warszawy, przeprowadzanych w dniu 19 czerwca 1994 roku. M.P. 1994 Nr 35, poz. 304; Obwieszczenie Państwowej Komisji Wyborczej z dnia 23 października 1998 roku. Dz. U. 1998 Nr 131, poz. 861; http://pkw.gov.pl/ (dostęp: 29.12.2014); 19 czerwca 1994 r. Wybory do rad gmin. Statystyka wyborów. PKW/GUS, Warszawa 1994.

Jak pokazują dane prezentowane w tabeli 2, poziom partycypacji mieszkańców Katowic jest najniższy w porównaniu ze zmiennymi uzyskiwanymi w województwie śląskim, Polsce oraz na poziomie gmin (tutaj uwzględniane są także wyniki w miastach na prawach powiatu). Wyjątkiem były wybory w 1990 roku, kiedy frekwencja w mieście była nieznacznie wyższa niż średnia frekwencja w województwie katowickim i polskiej gminie. Niechęć do uczestnictwa w wyborach może wynikać $\mathrm{z}$ wielu przyczyn, które są analizowane w literaturze podmiotu. Warto odnieś się do tych uzyskanych i opisanych przez Centrum Badania Opinii Społecznej w związku z poprzednimi wyborami samorządowymi w Polsce w 2010 roku. Okazuje się, że wpływ na absencję wyborczą mogą

10 BS/132/2010, Wybory samorządowe - znaczenie, zainteresowanie oraz deklaracje udziału w głosowaniu, Centrum Badania Opinii Publicznej, Warszawa, wrzesień 2010. 
mieć młody wiek, niskie wykształcenie, zła ocena sytuacji materialnej przez obywatela, a także jego mała religijność. Poza tym respondenci podkreślali brak zainteresowania polityką i negatywny stosunek do aktu wyborczego ${ }^{11}$. Ale przedstawione powyżej czynniki nie wyjaśniają do końca przyczyn niższej absencji w Katowicach w porównaniu $\mathrm{z}$ innymi obszarami. O pewnej specyfice określonego poziomu frekwencji w wyborach samorządowych w Katowicach można się przekonać po analizie frekwencji w innych miastach konurbacji górnośląskiej. Wyraźnie widać, że frekwencja uzyskiwana w tych miastach ma pewną stałą tendencję. Miastem, które zajmuje miejsce w pierwszej trójce pod względem wysokości frekwencji w wyborach samorządowych wśród kilkunastu miast górnośląskiego obszaru, są Mysłowice (2002 rok: 38\%, 2006 rok: 42,32\%, 2010 rok: 50,46\%, 2014 rok: 36,73\%). Natomiast miastem, które notorycznie notuje najniższe poziomy frekwencji, jest Zabrze (2002 rok: 25,86\%, 2006 rok: 27,58\%, 2010 rok: 32,59\%, 2014 rok: 23,96\%). Różnica średniej frekwencji między liderem w wysokości uzyskiwanej partycypacji wyborczej, czyli Mysłowicami i Zabrzem będącym najmniej zaangażowanym w udział w wyborach samorządowych w XXI wieku wynosi 13,88\%. Średnia frekwencja w omawianym okresie w Katowicach wynosi 35,23\%, w Mysłowicach 41,87\%, a w Zabrzu 27,88\%. Można zatem w przybliżeniu stwierdzić, że poziom frekwencji wyborczej w wyborach samorządowych w Katowicach oscyluje w średnich granicach uzyskiwanych w miastach konurbacji górnośląskiej. Potwierdzenie tej tezy wymaga jednak przeprowadzenia dokładniejszych badań we wszystkich miastach omawianego regionu.

Niestety, porównanie średniej frekwencji w Katowicach z tą uzyskiwaną na poziomie obszaru województwa śląskiego, Polski i gmin w Polsce wypada dużo gorzej. Począwszy od 1990 do 2014 roku średnia frekwencja w wyborach samorządowych w Katowicach wynosi 34,35\%, w województwie śląskim (od 1998 roku) 40,29\%, w Polsce 43,67\%, a w gminach $42,49 \%$. W podanych przypadkach jest wyższa od katowickiej o 5,94\% (województwo śląskie), 9,32\% (Polska) i 8,14\% (gminy). Należy podkreślić, że poziom katowickiej frekwencji samorządowej wpisuje się w ogólnie niski trend obserwowany w województwie śląskim. To województwo notuje bowiem stosunkowo niską frekwencję na tle innych w poszczególnych wyborach. W 2002 roku województwo śląskie odnotowało najniższą pozycję wśród 16 województw, a od 2006 do 2014 roku zajmowało 15. pozycję przed sąsiednim województwem, opolskim.

Istnieje powszechne przekonanie, że wybory samorządowe obejmują następujące elekcje: do rad gmin (miast na prawach powiatu), rad powiatów, sejmików województw i na urzędy wójtów, burmistrzów i prezydentów. Jest jeszcze jeden poziom, który może być objęty określeniem wyborów samorządowych, a odnosi się on do wyborów do rad jednostek pomocniczych. Kompetencję do tworzenia jednostek pomocniczych polski ustawodawca przyznał gminie, $\mathrm{w}$ której rada $\mathrm{w}$ drodze uchwały po przeprowadzeniu konsultacji z mieszkańcami lub $\mathrm{z}$ ich inicjatywy może dokonać tego aktu. Powołanie jednostki pomocniczej ma charakter fakultatywny. Jak wskazuje ustawa o samorządzie gminnym, jednostka pomocnicza staje się nią dopiero po powołaniu do życia organów

11 BS/171/2010, O wyborach samorządowych po obu turach głosowania. Komunikat z badań, Centrum Badania Opinii Publicznej, Warszawa, grudzień 2010. 
władzy: uchwałodawczego i wykonawczego ${ }^{12}$. Same jednostki mogą mieć różne nazwy, ustawa proponuje, aby na wsiach nazywały się sołectwami, a w miastach dzielnicami i osiedlami. Nie jest to jednak katalog zamknięty i istnieją inne nazwy, jak osada, kolonia, kwartał, przysiółek, wspólnota samorządowa itp. ${ }^{13} \mathrm{~W}$ nazwanych jednostkach rada jest organem uchwałodawczym w dzielnicach i osiedlach, a zebranie mieszkańców w sołectwach. Chociaż osiedla mogą zdecydować, że zebranie mieszkańców będzie ich organem uchwałodawczym. Organami wykonawczymi w sołectwie jest sołtys, a w dzielnicach i osiedlach zarząd. W aspekcie wyborczym, jednostki pomocnicze będą nas interesowały wyłącznie wtedy, gdy będzie w nich dochodziło do wyborów, a to dzieje się w jednostkach pomocniczych w miastach (gminach miejskich) w przypadku rad, gdyż zarządy są wyłaniane pośrednio przez rady. W sołectwach funkcjonują mechanizmy demokracji bezpośredniej, jaką jest zebranie wszystkich mieszkańców.

Jak wskazuje Sylwester Wróbel, w kwestii sposobów przeprowadzania wyborów do rad jednostek pomocniczych występuje zróżnicowanie. Część miast przeprowadza wybory powszechne z użyciem kart wyborczych, występowaniem komisji wyborczych i zastosowaniem systemu wyborczego większości względnej, rzadziej proporcjonalnego. W niektórych miastach stosowane są procentowe progi frekwencji, po przekroczeniu, których wybory uznaje się za ważne. Jednostka może stanowić jeden okręg, gdzie wyłania się cały skład rady, lub może być podzielona na mniejsze jednostki, w których wybierana jest odpowiednia część radnych. Innym sposobem wyboru rad jest zwołanie zebrania mieszkańców jednostki pomocniczej. Tutaj też można ustanowić wymóg prawomocności obrad i wyborów w postaci obecności odpowiedniej liczby mieszkańców. Na zebraniu uczestnicy imiennie zgłaszają kandydatów, którzy są następnie wybierani ${ }^{14}$.

Rada Miejska Katowic podjęła w 1991 roku dwie uchwały, które tworzyły na terenie miasta jednostki pomocnicze i określały statut tych podmiotów. Władze miejskie postanowiły podzielić obszar gminy na 22 jednostki pomocnicze, które wówczas nazwano wspólnotami samorządowymi. W 1997 roku dokonano korekty podziału, ale pozostawiono tę samą liczbę jednostek ${ }^{15}$. W przyjętym przez uchwałodawcę rozwiązaniu zdecydowano, że wybory do rad jednostek pomocniczych będą miały charakter powszechny i zostaną przeprowadzane przez terytorialne komisje wyborcze. Oznaczało to upodobnienie tych wyborów do elekcji na poziomie gmin. Na przestrzeni ponad dwóch dekad

12 Ustawa z dnia 8 marca 1990 roku o samorządzie gminnym, Dz.U. Nr 16, poz. 95 z 1990 r. z późn. zm., art. 5, pkt. 1, 2 .

${ }^{13}$ K. Bandarzewski et al., Jednostki pomocnicze gminy, Kraków 2002, s. 52; M. Augustyniak, Tworzenie, łaczenie, podział i znoszenie jednostek pomocniczych gminy, [w:] Samorząd miejski. Zadania, instytucje, formy, red. S. Wróbel, Poznań-Chorzów 2008, s. 243.

14 S. Wróbel, Tworzenie i zakres odrębności jednostek pomocniczych gminy, „Zeszyty Naukowe Wyższej Szkoły Bankowej w Poznaniu Wydziału Zamiejscowego w Chorzowie” 2006, nr 7, s. 244-245.

${ }^{15}$ Uchwała Rady Miejskiej Katowic z dnia 25 lutego 1991 roku w sprawie statutu wspólnot samorządowych, Nr XVI/81/91; Uchwała Rady Miejskiej Katowic z dnia 16 września 1991 roku w sprawie utworzenia na terenie miasta Katowice 22 pomocniczych jednostek samorządowych i podziału miasta na 22 obszary ich działania, Nr XXVI/148/91; Uchwała Rady Miejskiej Katowic z dnia 29 września 1997 roku w sprawie nazw i granic obszarów działania jednostek pomocniczych samorządu na terenie miasta Katowice, $\mathrm{Nr}$ XLVI/449/97. 
prawo wyborcze ewoluowało ${ }^{16}$. Na podstawie uchwały z 1991 roku wyborca dokonywał wyboru przez pozostawienie nazwisk nieskreślonych kandydatów w liczbie nie większej niż liczba członków rady. W 1998 roku wprowadzono nowe zasady wyborcze, które przewidywały, że w przypadku frekwencji mniejszej niż $10 \%$ wybory do rady uznawano za nieważne. Jak pokazała przyszłość, było to kryterium, które w kilku przypadkach doprowadziło do unicestwienia jednostek pomocniczych. Dlatego w ostatniej uchwale z 2004 roku regulującej prawo wyborcze zrezygnowano z tego wymogu ${ }^{17}$.

W okresie pomiędzy pierwszymi wyborami do rady jednostki pomocniczej w Katowicach (1993 rok) a tymi, które odbyły się w 2014 roku, przeprowadzono łącznie 53 elekcje, przy czym z 22 obszarów wyznaczonych na działanie owych jednostek, jedynie w 15 doszło do co najmniej jednej elekcji. Wybory odbywają się po raz pierwszy w jednostce wówczas, gdy mieszkańcy zgłoszą inicjatywę powołania takiej jednostki i jeżeli liczba kandydatów jest co najmniej o 50\% większa niż przypadająca w danej jednostce liczba wybieranych radnych. W przypadku Katowic rady liczą od 15 do 21 radnych. Wybory są przeprowadzane w cyklu czteroletnim.

Założenie poprzedzające badania nad frekwencją uzyskiwaną w wyborach do rad jednostek pomocniczych w Katowicach opiera się na wskazanej wcześniej tezie o drugorzędności wyborów samorządowych. Skoro wybory do organów uchwałodawczych polskiego samorządu terytorialnego i organów wykonawczych w gminach i miastach na prawach powiatu cieszą się małym zainteresowaniem wśród elektoratu (trzecie, przedostatnie miejsce) to wybory do rad będących ciałami jednostek mniejszych będą odzwierciedlały jeszcze mniejszą popularność. Warto jednak pamietać o argumentach partycypacjonistów, którzy uważają, że rozszerzanie zakresu demokracji bezpośredniej pozytywnie wpływa na kształtowanie się postaw obywatelskich w społeczeństwie. Niewątpliwie wybory do rad jednostek pomocniczych przybliżają władzę społeczeństwu i umożliwiają udział w podejmowaniu decyzji na obszarze najbliższym codziennemu funkcjonowaniu obywateli, czyli w ich dzielnicach i osiedlach ${ }^{18}$.

W tabeli 3 przedstawiono wartości frekwencji uzyskiwane w każdej z 53 elekcji do rad jednostek pomocniczych miasta Katowice. Ponieważ wybory do rad nie pokrywają się z wyborami do rady miasta Katowice, dlatego, uwzględniając kryterium systematyzacyjne wynikające z cykliczności elekcji i cech pojawiających się w określonym czasie, dokonano podziału wyborów na 6 okresów. Kryterium podziału odnosiło się do liczby inicjatyw powołania jednostki pomocniczej, rzeczywistej liczby ich funkcjonowania, występującego systemu wyborczego czy też stosunku władz do jednostek pomocniczych. Oprócz frekwencji tabela zawiera daty poszczególnych wyborów.

16 S. Kubas, Wybory do rad jednostek pomocniczych miasta Katowice w latach 1993-2010, [w:] Rola samorządu terytorialnego $w$ modernizacji Polski, red. M. Barański, A. Czyż, S. Kubas, Katowice 2010, s. 275-282.

17 Uchwała Rady Miejskiej Katowic z dnia 16 marca 1998 roku w sprawie trybu wyborów do rad jednostek pomocniczych samorządu na terenie miasta Katowice, Nr L/526/98; Uchwała Rady Miejskiej Katowic z dnia 9 lutego 2004 roku Statut Miasta Katowice, Nr XX/340/04.

18 M. Marczewska-Rytko, Demokracja bezpośrednia w teorii i praktyce politycznej, Lublin 2001, s. 107. 
Uzyskane dane wskazują, że wybory do rad jednostek pomocniczych Katowic nie cieszą się popularnością wśród elektoratu. Nie potwierdza to założenia o chęci korzystania z mechanizmów demokracji bezpośredniej przez mieszkańców stolicy województwa śląskiego. Potwierdza się natomiast teza o tym, że wybory do rad jednostek są traktowane, przez elektorat jako kolejne, w których niechętnie uczestniczy. Wpływ na taką postawę może mieć brak wiedzy o istnieniu samych jednostek pomocniczych, a także jeżeli już zaistnieją w świadomości, to nieprzypisywanie im istotności w strukturze życia publicznego.

Średnia frekwencja w wyborach do rad w odniesieniu do sześciu cykli wyborczych, z których cztery ostatnie przypadają na XXI wiek, kształtuje się na poziomie 9,86\%. Największe wahania notowała w pierwszych okresach poddawanych próbie badawczej, które przypadły na lata 90 . XX wieku (2,7\% i 19,2\%), a od trzeciego do szóstego okresu ustabilizowała się w okolicach $10 \%(8,43 \%, 9,25 \%, 8,7 \%, 10,91 \%)$. Jeżeli jednak przypatrzeć się dokładnie poszczególnym jednostkom, można zauważyć istotne różnice w partycypacji wyborczej.

Najwyższa średnia frekwencja występuje w Zarzeczu (20,38\%) oraz Podlesiu (20,34\%). Są to dzielnice zamieszkiwane od pokoleń przez rdzennych Katowiczan, występują tutaj tradycyjne i bliskie relacje międzysąsiedzkie, co pozytywnie wpływa na aktywność obywateli w lokalnym życiu publicznym. Najniższą średnią frekwencję odnotowano na osiedlu Tysiąclecia (1,82\%), które jest kilkunastotysięcznym konglomeratem osób przyjezdnych. Trudno w nim o bliskie, długotrwałe i tradycyjne relacje. Jest to wynik architektonicznej zabudowy, na którą składają się kilkunastopiętrowe bloki mieszkalne. Najwyższa jednostkowa frekwencja została zanotowana 11 października 1998 roku w Panewnikach-Ligocie: 31,5\%, a najniższa 25 kwietnia 1993 roku na Osiedlu Tysiąclecia: 0,63\% ${ }^{19}$.

Poziom zainteresowania mieszkańców Katowic wyborami samorządowymi okazuje się mało satysfakcjonujący, a uwzględniając wybory do rad jednostek pomocniczych, można stwierdzić, że jest wyjątkowo niski. Potwierdza to tezę o drugorzędności wyborów samorządowych. Jak wygląda zatem partycypacja Katowiczan w wyborach, które są postrzegane, jako pierwszorzędne (parlamentarne i prezydenckie)? W analizie porównawczej zostaną także uwzględnione wybory do Parlamentu Europejskiego. W tabeli 4 odnotowano poziomy średniej frekwencji we wszystkich typach wyborów, w jakich uczestniczą mieszkańcy Katowic. W celu ukazania porównania poziomu zainteresowania wyborami samorządowymi (rada miasta i prezydent, sejmik województwa) i wyborami do rad jednostek pomocniczych mieszkańców poszczególnych dzielnic i osiedli, dokonano pewnej systematyzacji. Polegała ona na tym, że frekwencje z wyborów do rad jednostek zostały odniesione do okręgów, w których owe jednostki się znajdują. Okręgi te są wykorzystywane przy wyborach do rady miasta. Na tej podstawie będzie można stwierdzić, czy mieszkańcy danych jednostek pomocniczych uczestniczą $\mathrm{w}$ wyborach do rady i na prezydenta miasta $w$ podobnym, czy też innym zakresie niż w wyborach do rad jednostek pomocniczych.

19 S. Kubas, Istotność wyborów do rad jednostek pomocniczych w Katowicach w perspektywie władz samorządowych, elektoratu i kandydatów, [w:] Jednostki pomocnicze w polskich gminach. Pozycja, funkcje i wyzwania, red. A. Jarosz, B. Springer, Zielona Góra 2014, s. 197-209. 


\begin{tabular}{|c|c|c|c|c|c|c|c|c|}
\hline 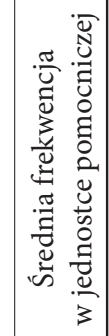 & $\stackrel{\stackrel{े}{0}}{\stackrel{0}{-}}$ & $\begin{array}{l}\stackrel{0}{\hat{N}} \\
\stackrel{0}{\sim}\end{array}$ & $\begin{array}{l}\stackrel{0}{\hat{N}} \\
\hat{n} \\
\hat{\jmath}\end{array}$ & $\begin{array}{l}\text { ले } \\
\text { in }\end{array}$ & $\begin{array}{l}\text { वे } \\
0 \\
0 \\
\text { nీ }\end{array}$ & $\begin{array}{l}\stackrel{े}{\circ} \\
\stackrel{+}{+}\end{array}$ & 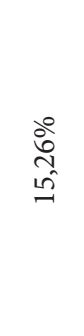 & $\begin{array}{l}0 \\
8 \\
\infty \\
0 \\
0\end{array}$ \\
\hline $\begin{array}{l}\stackrel{+}{\vec{D}} \\
\stackrel{\sim}{1} \\
\stackrel{\sim}{\vec{N}}\end{array}$ & 1 & 1 & 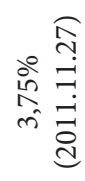 & 1 & 1 & 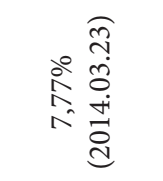 & 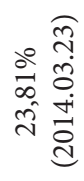 & 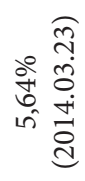 \\
\hline 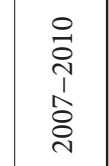 & 1 & 1 & 1 & 1 & 1 & 1 & 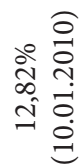 & 1 \\
\hline 亗 & 1 & 1 & 1 & 1 & 1 & 1 & 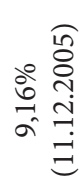 & 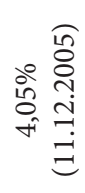 \\
\hline 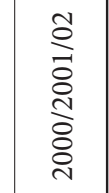 & 1 & 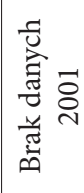 & 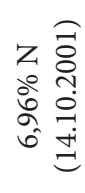 & 1 & 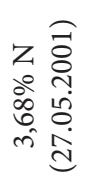 & 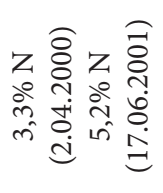 & 1 & 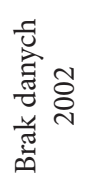 \\
\hline$\frac{\frac{\infty}{\hat{a}}}{\frac{a}{2}}$ & 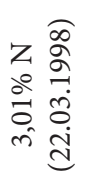 & 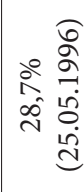 & 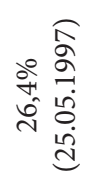 & 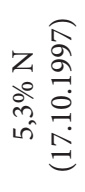 & 1 & 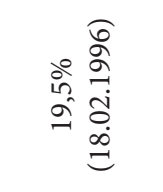 & 1 & 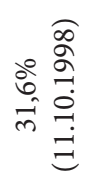 \\
\hline 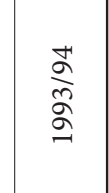 & 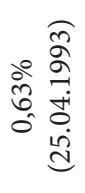 & 1 & 1 & 1 & 1 & 1 & 1 & 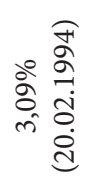 \\
\hline 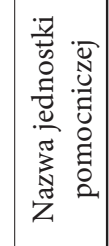 & 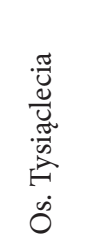 & ڤే & 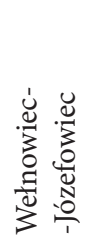 & 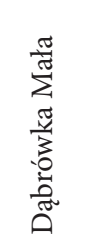 & 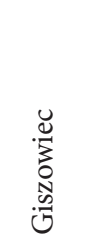 & 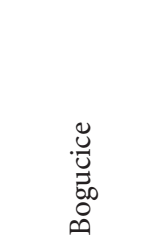 & $\frac{\vec{z}}{\underline{\Xi}}$ & 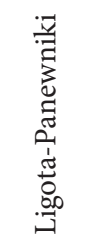 \\
\hline
\end{tabular}




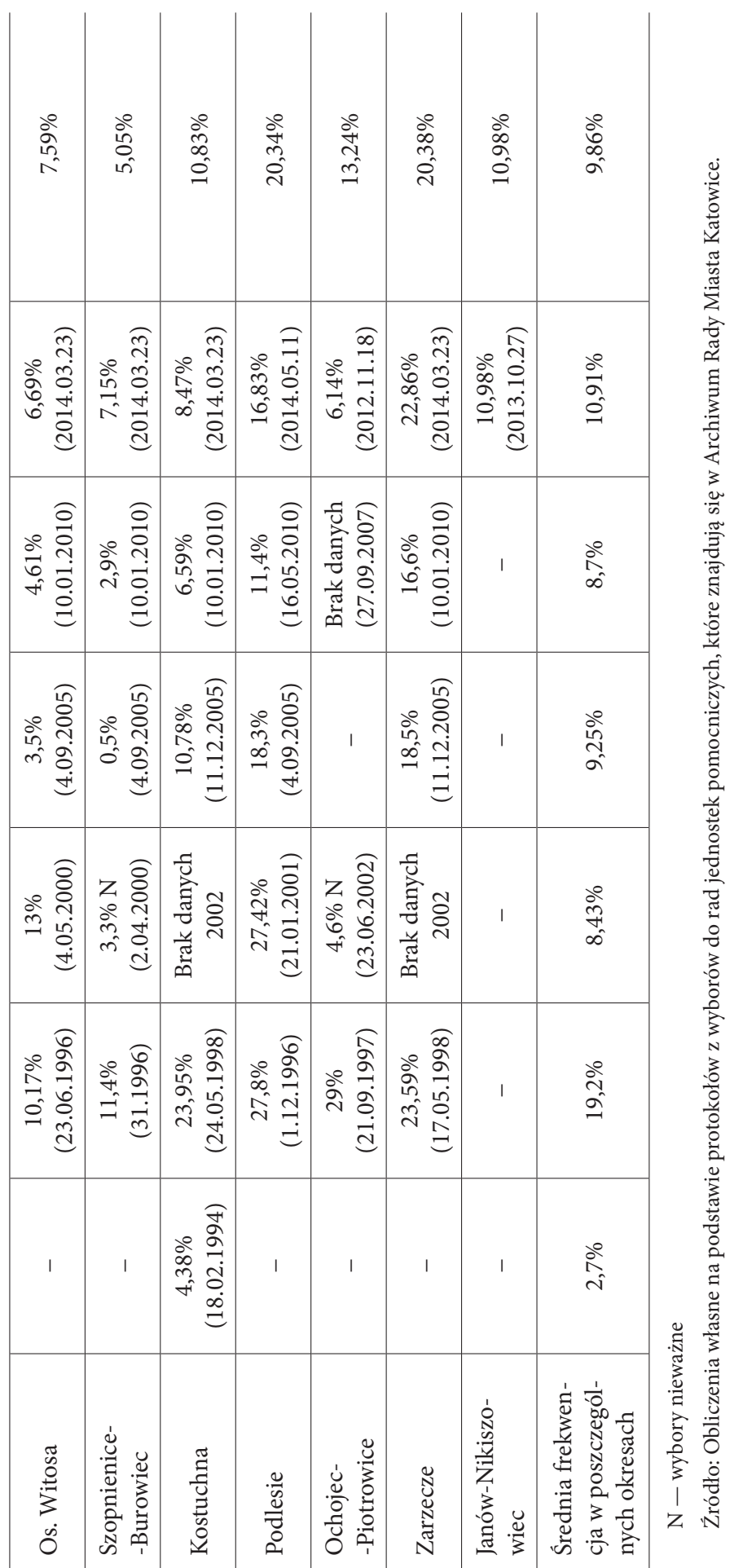




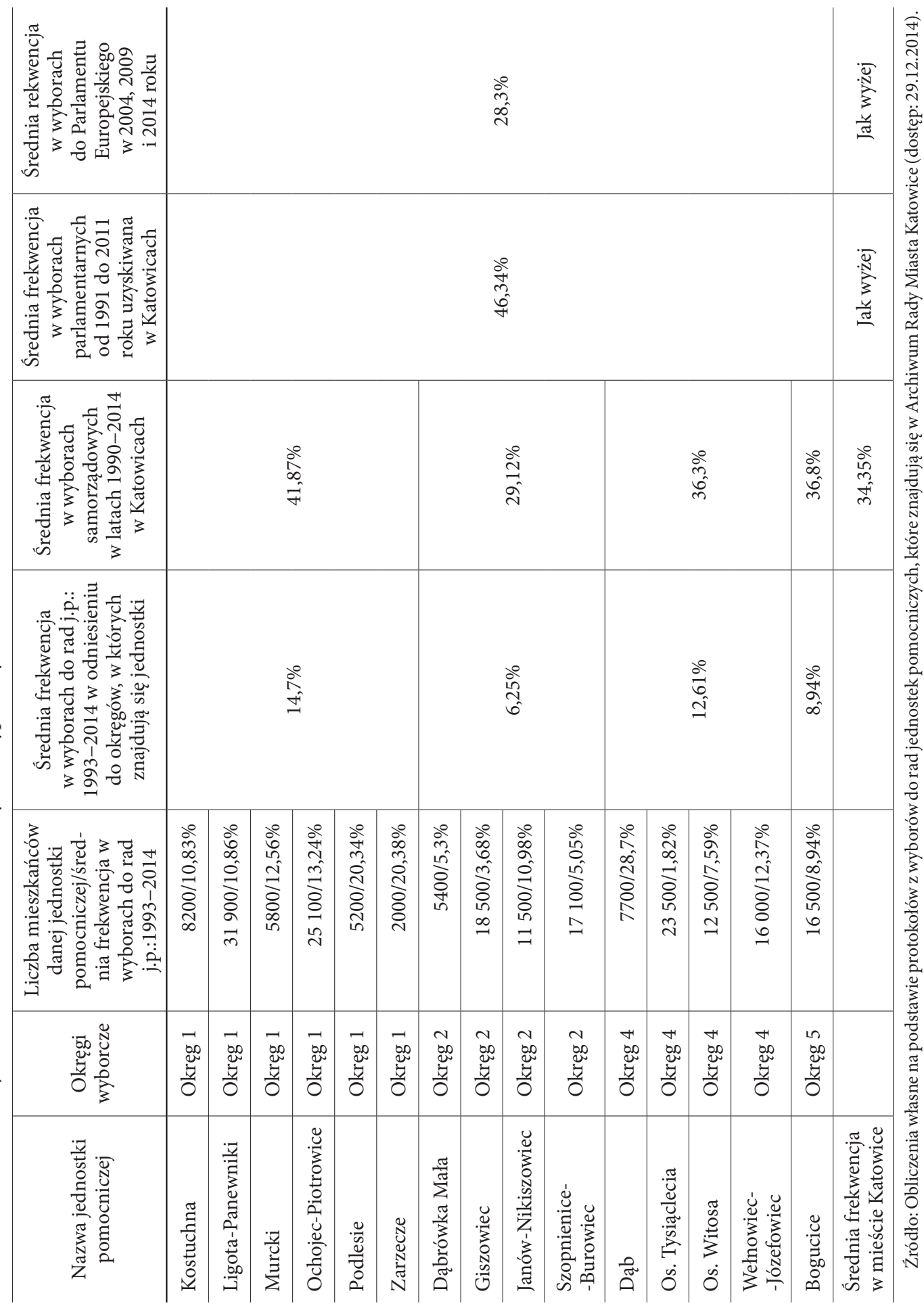


Średnia frekwencja w wyborach samorządowych w Katowicach wynosi 34,35\%. Natomiast w wyborach do rad jednostek pomocniczych 9,86\%. Dysproporcja jest ogromna (różnica sięga 24,49\%). Po porównaniu poziomu partycypacji mieszkańców poszczególnych jednostek pomocniczych w wyborach samorządowych i w wyborach do rad jednostek pomocniczych okazuje się, że występują tutaj podobne różnice, jak na poziomie ogólnego porównania (okręg nr 1: średnia frekwencja w wyborach do rad jednostek wynosi $14,7 \%$, a samorządowych $41,48 \%$, różnica to $27,08 \%$; okręg nr 2: średnia frekwencja w wyborach do rad jednostek wynosi 6,25\%, a samorządowych $29,12 \%$, różnica to 22,87\%\%; okręg nr 3 nie jest reprezentowany przez żadną jednostkę pomocniczą; okręg $\mathrm{nr} 4$ : średnia frekwencja w wyborach do rad jednostek wynosi 12,61\%, a samorządowych $36,3 \%$, różnica to $23,69 \%$; okręg nr 5: średnia frekwencja w wyborach do rad jednostek wynosi $8,94 \%$, a samorządowych $36,8 \%$, różnica to $28,78 \%$ ). Można stwierdzić, że istnieje ścisła korelacja frekwencji w jednostkach pomocniczych w trakcie wyborów do rad $\mathrm{z}$ tą, która występuje w wyborach samorządowych. Tam, gdzie wyborcy (mieszkańcy poszczególnych dzielnic i osiedli) chętniej partycypują w elekcjach do rad, także częściej biorą udział w wyborach samorządowych.

Jeżeli wziąć pod uwagę różnicę frekwencji pomiędzy wyborami do rad jednostek pomocniczych (9,86\%) i wyborami do Parlamentu Europejskiego (28,3\%), wyniesie ona 18,44\% i będzie niższa od tej, która pojawia się w porównaniu z wyborami samorządowymi. Natomiast wyraźnie zwiększy się, gdy dokona się porównania z wyborami parlamentarnymi i prezydenckimi. Różnica poziomu średniej frekwencji z wyborów do rad jednostek pomocniczych $(9,86 \%)$ i frekwencji z wyborów do Sejmu i Senatu $(46,34 \%)$ wynosi $36,48 \%$. Różnica poziomu średniej frekwencji z wyborów do rad jednostek pomocniczych $(9,86 \%)$ i frekwencji z prezydenckich $(59,04 \%)$ jest jeszcze wyższa i wynosi $49,54 \%^{20}$.

Porównanie frekwencji uzyskiwanej w wyborach samorządowych i prezydenckich oraz parlamentarnych w Katowicach wskazuje, że ta pierwsza jest najniższa. Jedynie frekwencja w wyborach do Parlamentu Europejskiego jest notowana na niższym poziomie. Jeszcze niższy poziom frekwencji występuje w wyborach do rad jednostek pomocniczych.

\section{Wskaźnik głosów nieważnych jako negatywny aspekt partycypacji}

Charakter uczestnictwa w wyborach może być także wyrażony poprzez zakres liczby nieważnie oddanych głosów. Odzwierciedla to negatywne podejście elektoratu do procesu wyłaniania przedstawicieli lub nieznajomość procedur. W Katowicach w 1990 roku w wyborach do rady miasta odsetek głosów nieważnych wyniósł 4,1\%, z roku 1994 i 1998 brak jest danych, w 2002 roku 3,91\%, w 2006 roku 2,46\%, w 2010 roku 2,42\%, w 2014 roku 8,9\%. W skali ogólnopolskiej w odniesieniu do rad gmin (miast na prawach powiatu od 1998 roku) dane przedstawiają się następująco: 1990 rok -2,97\%, 1994 rok $-1,78 \%, 1998$ rok $-2,58 \%, 2002$ rok $-4,18 \%, 2006$ rok $-3,77 \%, 2010$ rok $-3,66 \%$, 2014 rok - 5,16\%. Należy jednak zaznaczyć, że od 1998 roku o wiele wyższy był zakres

\footnotetext{
${ }^{20}$ Ibidem.
} 


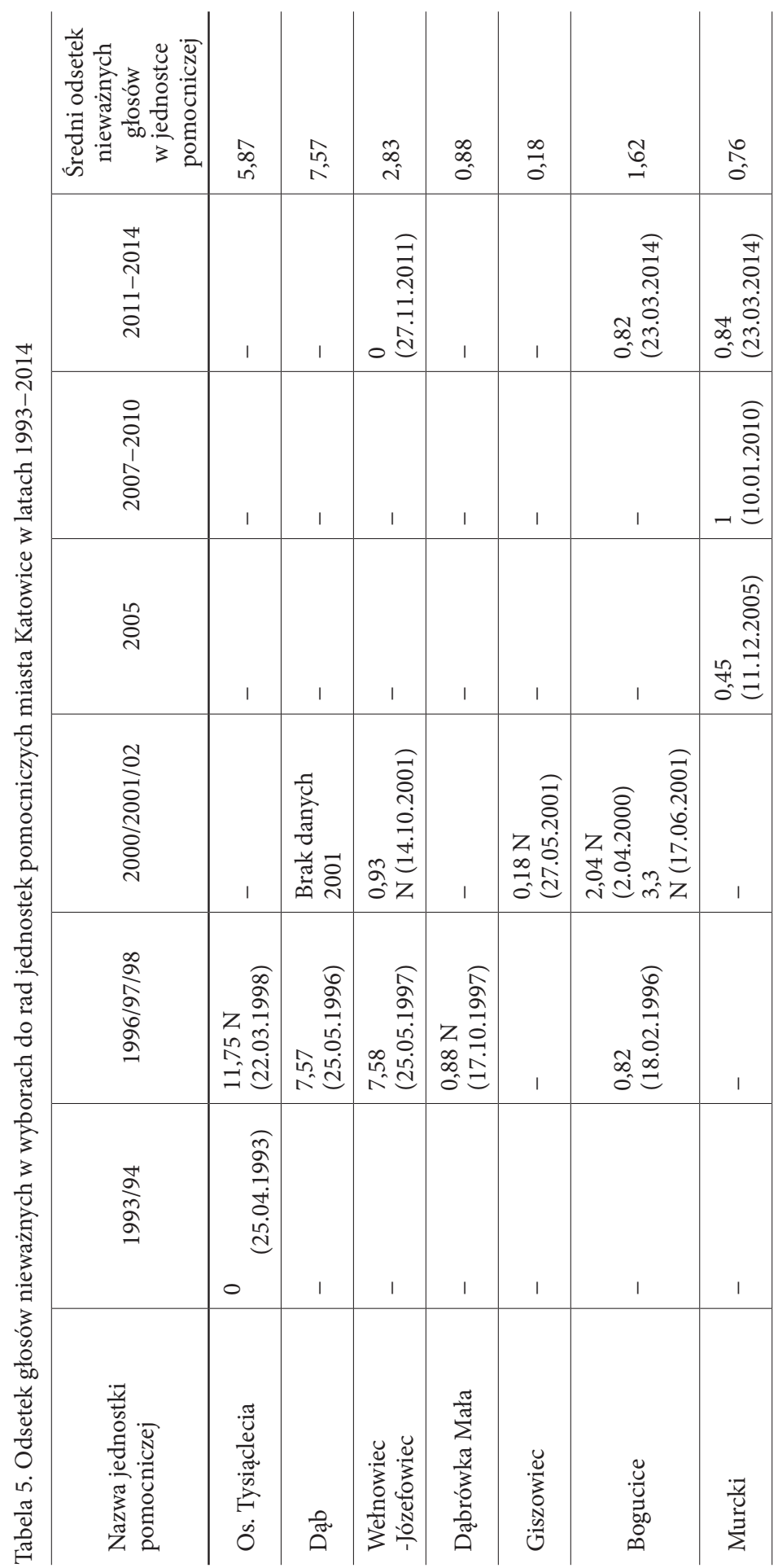




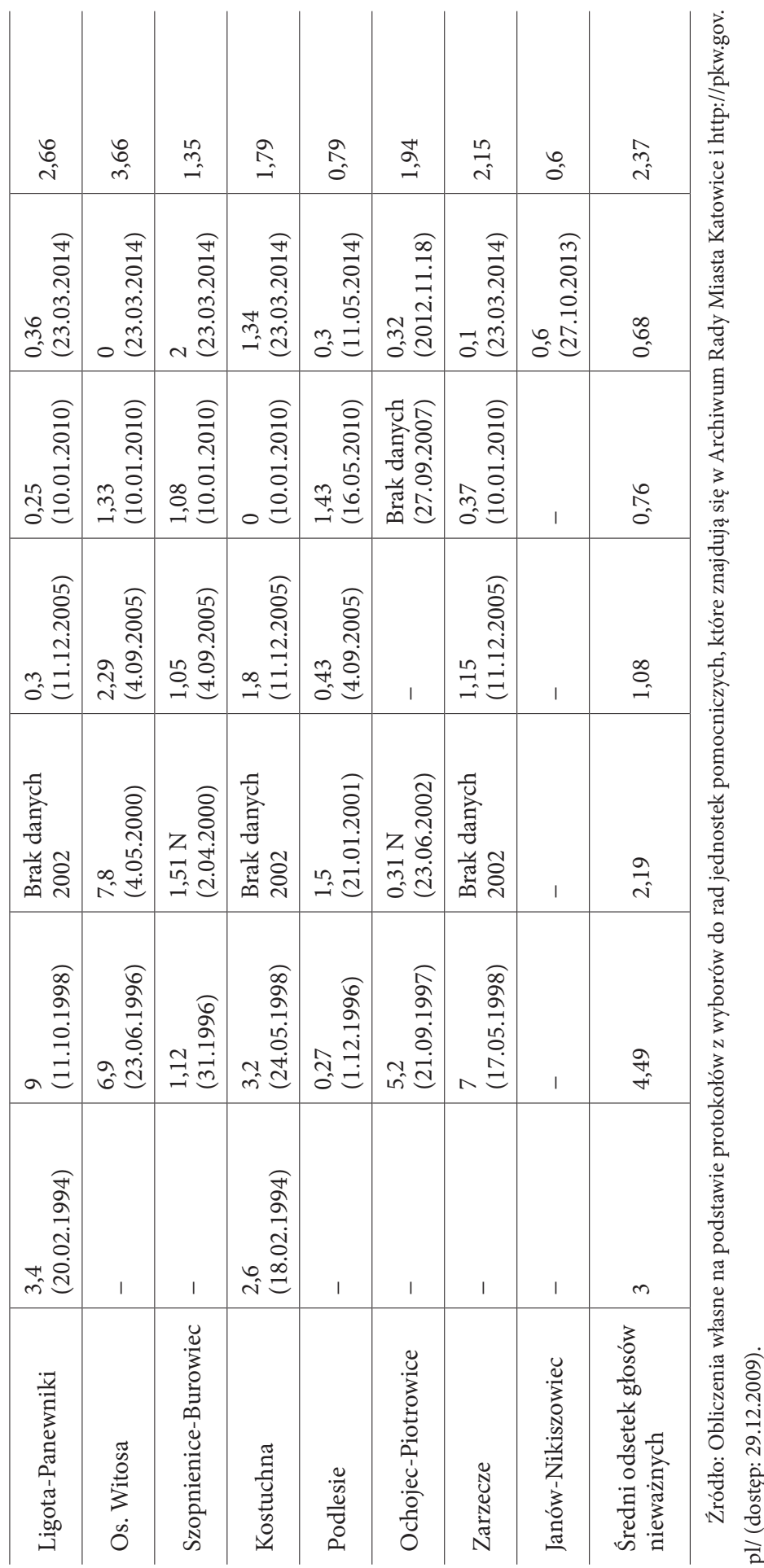


nieważnie oddawanych głosów w wyborach na poziomie rad powiatów i sejmików województw. W odniesieniu do rad powiatów wynosił odpowiednio: 1998 rok $-7,43 \%$, 2002 rok $-8,59 \%$, w 2006 roku $-8,3 \%$, w 2010 roku $-8,18 \%$, w 2014 roku $-16,67 \%$. W odniesieniu do sejmików województw: 1998 rok $-9,45 \%, 2002$ rok $-14,43 \%$, 2006 rok - 12,7\%, 2010 rok - 12,06\%, 2014 rok - 17,93\% ${ }^{21}$. Jeżeli uwzględni się odsetek nieważnych głosów w wyborach na urząd prezydenta Katowic, a następnie organów wykonawczych gmin i miast na prawach powiatu w Polsce, zarysuje się pewna prawidłowość. W 2002 roku procent liczby nieważnych głosów w Katowicach w wyborach na prezydenta wyniósł 1,51\%, w 2006 roku - 0,83\%, a w 2010 roku 0,61\%, w 2014 roku $1,3 \%$. W skali ogólnopolskiej wyglądało to następująco: 2002 rok - 2,33\%, w 2006 roku $-1,91 \%, 2010$ rok $-1,66 \%, 2014$ rok $-2,14 \%^{22}$. Prawidłowość, o której wspomniano, charakteryzuje się tym, że wyborca chętniej głosuje na tych kandydatów, którzy w jego przekonaniu są bliżej niego, znajdują się w jego otoczeniu. Tym można tłumaczyć mniejszą liczbę nieważnych głosów w wyborach do rad gmin i na urzędy wójtów, burmistrzów i prezydentów w porównaniu z wyborami do rad powiatów i sejmików województw. Nie bez znaczenia jest tutaj personalizacja aktu głosowania, która polega na tym, że bardziej znamy kandydatów do rad gmin i na urzędy wójtów, burmistrzów i prezydentów niż do rad powiatów i sejmików województw. Kolejnym powodem wyższego odsetka głosów nieważnych w wyborach do rad powiatów i sejmików może być wyższy poziom upolitycznienia (upartyjnienia) tych organów, a także nieznajomość procedur głosowania. Poza tym reguły wyborów na wójtów, burmistrzów i prezydentów są niewątpliwie prostsze niż na przykład w wyborach do sejmików województw.

W analizowanych typach wyborów w trzech elekcjach w XXI wieku okazuje się, że mieszkańcy Katowic oddają mniej nieważnych głosów niż średnio mieszkańcy Polski. Może to świadczyć o wyższym poparciu dla samego aktu głosowania, co jednak w zestawieniu z niską frekwencją, jest trudne do udowodnienia. Bardziej zasadne wydaje się twierdzenie, że Katowiczanie lepiej rozumieją procedury i zasady głosowania, a także popełniają mniej błędów w trakcie aktu oddawania głosu.

Weryfikacji przedstawionych powyżej założeń można dokonać poprzez analizę danych płynących z wyborów do rad jednostek pomocniczych. Jeżeli zauważyć, że generalnie Katowiczanie oddają mniej nieważnych głosów w wyborach do rady miasta, sejmiku województwa i na urząd prezydenta, niż przeciętnie czynią to Polacy, to w wyborach do organów będących najbliżej, czy do rad dzielnic i osiedli, powinni oddawać jeszcze mniej nieważnych głosów, biorąc pod uwagę zmienną bliskości wybieranych kandydatów.

${ }^{21}$ Obwieszczenie Generalnego Komisarza Wyborczego Państwowej Komisji Wyborczej z dnia 31 maja 1990 roku o zbiorczych wynikach wyborów do rad gmin oraz na obszarze kraju, przeprowadzanych w dniu 27 maja 1990 roku. M.P. 1990 Nr 21, poz. 170; Obwieszczenie Państwowej Komisji Wyborczej z dnia 23 czerwca 1994 roku o zbiorczych wynikach wyborów do rad gmin oraz do Rady m. st. Warszawy, przeprowadzanych w dniu 19 czerwca 1994 roku. M.P. 1994, nr 35, poz. 304; Obwieszczenie Państwowej Komisji Wyborczej z dnia 23 października 1998 roku. Dz. U. 1998 Nr 131, poz. 861; J. Zbieranek, Głosy nieważne w wyborach samorzadowych, http://www.isp.org.pl/uploads/filemanager/prezentacjaogosachniewanychwwyborach.pdf (dostęp: 11.01.2015).

22 Strona Państwowej Komisji Wyborczej, http://pkw.gov.pl/ (dostęp: 11.01.2015). 
Średni odsetek głosów nieważnych we wszystkich wyborach do rad jednostek pomocniczych w Katowicach wynosi 2,37\%. Wyraźnie widać, że ulega on zmniejszeniu w każdym z kolejnych sześciu opisanych cykli wyborczych, a w czterech cyklach przypadających na XXI wiek średni odsetek głosów nieważnych wynosi zaledwie 0,95\%. Najmniejszą wartość przyjął podczas ostatniego cyklu: lata 2011-2014, gdy uzyskał 0,68\%. Aż cztery z pięćdziesięciu trzech elekcji charakteryzowały się brakiem głosów nieważnych wrzuconych do urn: 25 kwietnia 1994 roku na osiedlu Tysiąclecie, 1 października 2010 roku w Kostuchnie, 27 listopada 2011 roku w jednostce Wełnowiec-Józefowiec i 23 marca 2014 roku na osiedlu Witosa. Tylko jeden raz odsetek głosów nieważnych przekroczył $10 \%$, uzyskując $11,75 \%$, co miało miejsce na osiedlu Tysiąclecia 22 marca 1998 roku. W odniesieniu do średnich uzyskiwanych w poszczególnych jednostkach, przy założeniu przynajmniej dwukrotnie odbytych wyborów, najniższy średni odsetek głosów nieważnych występuje w dzielnicy Murcki: 0,76\%, a najwyższy na osiedlu Tysiąclecia: 5,87\%. Należy jednak zaznaczyć, o ile wszystkie analizowane wybory w Murckach odbywały się w XXI wieku, o tyle wybory brane pod uwagę na osiedlu Tysiąclecia miały miejsce w XX wieku. Gdyby wziąć pod uwagę wyłącznie elekcje w XXI wieku, to najwyższa średnia występuje na osiedlu Witosa: 2,85\%. W 22 poszczególnych elekcjach odsetek głosów nieważnych nie przekroczył 1\%.

Wydaje się zatem, że założenie o mniejszej liczbie głosów zmarnowanych i uważanych za nieważne na niższych szczeblach wyborów samorządowych, zostało potwierdzone w przypadku wyborów do rad jednostek pomocniczych miasta Katowice. Średni odsetek w wyborach do sejmików województw na poziomie ogólnopolskim wynosi 13,31\%, w wyborach do rad powiatów 9,83\%, a w wyborach do rad gmin 3,53\%. W Katowicach analizowana średnia w wyborach do rady miasta wynosi 3,22\% (z wyjątkiem lat 1994, 1998, 2014: brak danych). Średni odsetek głosów nieważnych w wyborach do rad jednostek pomocniczych Katowic wynosi $2,37 \%$ i jest o $0,85 \%$ niższy od wskaźnika charakteryzującego poziom wyborów do rady miasta Katowice.

\section{Podsumowanie}

Partycypacja wyborcza w wyborach samorządowych w Katowicach w ostatnim ćwierćwieczu odzwierciedla poziom i zakres istotności tych elekcji w oczach lokalnego elektoratu. Jak wskazują założenia teoretyczne, wybory samorządowe są określane jako drugorzędowe, a ich istotność niższa w ocenie wyborców niż wybory parlamentarne i prezydenckie. Przyjęta we wstępie teza została poddana weryfikacji za pomocą dwóch zmiennych: frekwencji wyborczej i głosów nieważnych. Po analizie zmiennych w wyborach samorządowych w Katowicach poddano je porównaniu ze zmiennymi uzyskiwanymi na poziomie ogólnopolskim i w jednostkach pomocniczych. Z przeprowadzonych badań można wysnuć kilka wniosków.

Po pierwsze, w odniesieniu do wyborów samorządowych w gminach (miastach na prawach powiatu), województwie śląskim i w Polsce, frekwencja uzyskiwana w Katowicach 
jest notowana na najniższym poziomie. Porównując średnią frekwencję w wyborach samorządowych w Katowicach ze średnią frekwencji w miastach konurbacji górnośląskiej, które zajmują czołowe (Mysłowice) i najniższe (Zabrze) miejsce, katowicka frekwencja plasuje się w środku. Frekwencja w województwie śląskim jest jedną z najniższych wśród wszystkich województw.

Po drugie, poziom frekwencji w wyborach do organów władzy samorządowej, które odbywają się w Katowicach, przyjmuje trzecią pozycję, za wyborami prezydenckimi i parlamentarnymi, a przed wyborami do Parlamentu Europejskiego.

Po trzecie, uwzględniając poziom elekcji samorządowych w jednostkach pomocniczych w Katowicach okazuje się, że uzyskiwana frekwencja jest najniższa w całej stawce przeprowadzanych wyborów. Występuje tutaj korelacja polegająca na tym, że mieszkańcy tych dzielnic i osiedli, którzy chętniej głosują w wyborach do rad, sejmików i prezydenta miasta, także chętniej uczestniczą w wyborach do rad jednostek pomocniczych.

Po czwarte, odsetek głosów nieważnych (po uśrednieniu), które występują w wyborach do rady miasta i na urząd prezydenta Katowic, jest niższy niż odsetek tych głosów, które występują w wyborach do rad gmin (miast na prawach powiatu) i na urzędy prezydentów w skali ogólnopolskiej. Odsetek głosów nieważnych jest również niższy niż ten, który występuje na poziomie wyborów do rad powiatów i sejmików województw.

Po piąte, $w$ wyborach do rad jednostek pomocniczych zakres głosów nieważnych jest jeszcze mniejszy niż w wyborach do rady miasta i na urząd prezydenta Katowic.

\section{Bibliografia}

19 czerwca 1994 r. Wybory do rad gmin. Statystyka wyborów, PKW/GUS, Warszawa 1994.

Augustyniak M., Tworzenie, łączenie, podziat i znoszenie jednostek pomocniczych gminy, [w:] Samorzą miejski. Zadania, instytucje, formy, red. S. Wróbel, Wydawnictwo Wyższej Szkoły Bankowej w Poznaniu, Poznań-Chorzów 2008.

Bandarzewski K., Chmielnicki P., Mączyński M., Płażek S., Jednostki pomocnicze gminy, Wydawnictwo PROMO, Kraków 2002.

Bąkiewicz M., Finansowe aspekty wyborów samorządowych, [w:] Samorząd terytorialny. Studium politologic$z n e$, red. J. Marszałek-Kawa, Dom Wydawniczy DUET, Toruń 2007.

BS/132/2010, Wybory samorządowe - znaczenie, zainteresowanie oraz deklaracje udziału w głosowaniu, Centrum Badania Opinii Publicznej, Warszawa, wrzesień 2010.

BS/171/2010, O wyborach samorządowych po obu turach głosowania. Komunikat z badań, Centrum Badania Opinii Publicznej, Warszawa, grudzień 2010.

Bukowski A., Komitety Obywatelskie - Ruch epoki przemian, „Studia Polityczne” 1994, nr 1-4.

Kubas S., Istotność wyborów do rad jednostek pomocniczych $w$ Katowicach $w$ perspektywie władz samorządowych, elektoratu i kandydatów, [w:] Jednostki pomocnicze w polskich gminach. Pozycja, funkcje $i$ wyzwania, red. A. Jarosz, B. Springer, Oficyna Wydawnicza Uniwersytetu Zielonogórskiego, Zielona Góra 2014.

Kubas S., Wybory do rad jednostek pomocniczych miasta Katowice w latach 1993-2010, [w:] Rola samorzadu terytorialnego w modernizacji Polski, red. M. Barański, A. Czyż, S. Kubas, Wydawnictwo Naukowe ŚLĄSK, Katowice 2010.

Marczewska-Rytko M., Demokracja bezpośrednia w teorii i praktyce politycznej, Wydawnictwo Uniwersytetu Marii Curie-Skłodowskiej, Lublin 2001. 
Obwieszczenie Generalnego Komisarza Wyborczego Państwowej Komisji Wyborczej z dnia 31 maja 1990 roku o zbiorczych wynikach wyborów do rad gmin oraz na obszarze kraju, przeprowadzanych w dniu 27 maja 1990 roku, M. P. Nr 21, poz. 170 z 1990 r.

Obwieszczenie Państwowej Komisji Wyborczej z dnia 23 czerwca 1994 roku o zbiorczych wynikach wyborów do rad gmin oraz do Rady m. st. Warszawy, przeprowadzanych w dniu 19 czerwca 1994 roku. M.P. Nr 35, poz. 304 z 1994 r.

Obwieszczenie Państwowej Komisji Wyborczej z dnia 23 października 1998 roku. Dz.U. Nr 131, poz. 861 z $1998 \mathrm{r}$.

Piasecki A.K., Wybory w Polsce, Wydawnictwo ARCANA, Kraków 2012.

Sokół W., Ewolucja systemu wyborczego do samorządu terytorialnego (1990-1997) - zasady i konsekwencje, [w:] Samorząd terytorialny III Rzeczypospolitej. Dziesięć lat doświadczeń, red. S. Michałowski, Wydawnictwo Uniwersytetu Marii Curie-Skłodowskiej, Lublin 2002.

Uchwała Rady Miejskiej Katowic z dnia 25 lutego 1991 roku w sprawie statutu wspólnot samorządowych, $\mathrm{Nr}$ XVI/81/91.

Uchwała Rady Miejskiej Katowic z dnia 16 września 1991 roku w sprawie utworzenia na terenie miasta Katowice 22 pomocniczych jednostek samorządowych i podziału miasta na 22 obszary ich działania, $\mathrm{Nr}$ XXVI/148/91.

Uchwała Rady Miejskiej Katowic z dnia 29 września 1997 roku w sprawie nazw i granic obszarów działania jednostek pomocniczych samorządu na terenie miasta Katowice, Nr XLVI/449/97.

Uchwała Rady Miejskiej Katowic z dnia 16 marca 1998 roku w sprawie trybu wyborów do rad jednostek pomocniczych samorządu na terenie miasta Katowice, $\mathrm{Nr}$ L/526/98.

Uchwała Rady Miejskiej Katowic z dnia 16 marca 1998 roku w sprawie trybu wyborów do rad jednostek pomocniczych samorządu na terenie miasta Katowice, Nr L/526/98.

Uchwała Rady Miejskiej Katowic z dnia 9 lutego 2004 roku Statut Miasta Katowice, Nr XX/340/04.

Ustawa z dnia 8 marca 1990 r. o samorządzie gminnym, Dz.U. Nr 16, poz. 95 z 1990 r. z późn. zm.

Wiszniowski R., Europejska przestrzeń polityczna. Zachowania elektoratu w wyborach do Parlamentu Europejskiego, Wydawnictwo Uniwersytetu Wrocławskiego, Wrocław 2008.

Wojtasik W., Funkcje wyborów w III Rzeczypospolitej. Teoria i praktyka, Wydawnictwo REMAR, Katowice 2012.

Wojtasik W., Drugorzędność wyborów samorządowych w teorii i badaniach empirycznych, [w:] Rola samorządu terytorialnego w modernizacji Polski, red. M. Barański, A. Czyż, S. Kubas, Wydawnictwo Naukowe ŚLĄSK, Katowice 2010.

Wróbel S., Tworzenie i zakres odrębności jednostek pomocniczych gminy, „Zeszyty Naukowe Wyższej Szkoły Bankowej w Poznaniu Wydziału Zamiejscowego w Chorzowie” 2006, nr 7.

\section{Źródło internetowe}

http://pkw.gov.pl/

Zbieranek J., Głosy nieważne w wyborach samorządowych, http://www.isp.org.pl/uploads/filemanager/ prezentacjaogosachniewanychwwyborach.pdf 


\section{Participation of the local community in Katowice in the elections to municipal authorities and the councils of facultative units. An analysis of a phenomenon on the basis of chosen factors}

Keywords: municipal elections in Katowice, turnout, invalid votes

\section{Summary}

The article presents the analysis of two factors connected with the local elections to municipal authorities in Katowice and to the councils of facultative units. The chosen factors: turnout and the number of invalid votes serve as a comparative tool of the attitudes of the local electorate in Katowice. The local turnout and the number of invalid votes in Katowice are primarily compared with the same factors connected with presidential, parliamentary and European Parliament elections, then the article touches upon the issue of elections to local municipal authorities and to the councils of facultative units in Katowice. 